\title{
Respon Model Gedung Beton Bertulang dengan Penambahan Dinding Pengisi terhadap Beban Gempa
}

(The Influence of Masonry Walls to Response of RC Building Models under Seismic Loads)

\author{
MUHAMMAD IBNU SYAMSI
}

\begin{abstract}
Earthquake-resistant building structures designs usually are not considering the influence of non-structural walls. In fact, non-structural walls could give additional strength for building especially to help retaining seismic loads. The Influence of masonry walls on infill frame building structure model to the open frame model became the objective in this study. Spectrum response and time history are applied to both types of model to know and compare the behavior of those two samples. The observed building is an educational facility and located in an area prone to earthquakes. The parameters used in this research are based on natural periods, shear forces, and drift ratios. After performing linear analysis, the drift ratio on each floor of the building could be categorized as safe condition because it has not exceeded its limit. Structural models with masonry walls have larger stiffness than open frames. Moreover, the greater structure stiffness in the infill frame model is able to narrow the drifts that occur from the inter-story drift ratio to be smaller. Due to higher stiffness, the base shear results from structures with infill frame system models are also larger than structures modeled with open frames system.
\end{abstract}

Keywords: infill frame, response spectrum, time history, drift, shear force

\section{PENDAHULUAN}

Gempa bumi adalah gerakan atau getaran yang terjadi di permukaan bumi yang diakibatkan oleh adanya pergerakan dua lempengan yang saling bergesekan yang menimbulkan pelepasan energi yang sangat besar secara tiba-tiba. Energi yang dilepaskan akan merambat ke segala arah hingga mencapai permukaan bumi. Getaran pada permukaan bumi tersebut dapat menyebabkan kerusakan pada struktur gedung diatasnya. Indonesia merupakan negara kepulauan yang secara geologis berada diantara tiga lempeng tektonik yaitu lempeng eurasia, lempeng pasifik dan lempeng indo-australia sehingga menyebabkan sebagian besar wilayah di Indonesia sering terjadi peristiwa gempa bumi tektonik. Ada beberapa gempa bumi besar yang pernah terjadi Indonesia seperti gempa bumi Aceh 26 Desember 2004 dengan kekuatan sebesar 9,3 SR, Gempa Yogyakarta 27 Mei 2006 sebesar 5,9 SR dan Gempa Sumatra Barat 30 September 2009 sebesar 7,6 SR. Tidak dapat dipungkiri bahwa kejadian-kejadian gempa tersebut mengakibatkan banyaknya korban jiwa, kerugian ekonomi, maupun kerugian infrastruktur.

Efek yang ditimbulkan oleh gaya gempa harus diperhitungan dalam suatu perencanaan struktur bangunan gedung sehingga diharapkan ketika terjadi gempa bumi yang besar walaupun terjadi kerusakan struktur gedung masih dapat tetap berdiri agar tidak membahayakan orang di dalamnya. Pada umumnya perencanaan bangunan tahan gempa tidak memperhitungkan pengaruh dinding non-struktural, padahal dinding non-struktural yang tersusun dari pasangan bata dapat memberikan tambahan kekakuan dan kekuatan yang signifikan pada struktur bangunan yang direncanakan terutama ketika gedung menerima beban gempa.

Tidke dan Jangave (2016) telah melakukan analisis untuk jenis model yang berbeda, ada 4 jenis struktur yang dimodelkan, i) bare frame ii) infill frame iii) masonry infill wall dengan 1 soft story iv) masonry infill wall dengan 2 tingkat soft story dengan dinding dibuat menggunakan metode "Equivalent Diagonal Strut". Hasil analisis mereka menyimpulkan bahwa struktur portal beton bertulang dengan pasangan dinding dengan atau tanpa soft story 
memiliki nilai base shear lebih tinggi dari pada portal bare frame, keberadaan pasangan dinding (masonry infill wall) mempengaruhi perilaku seismik dari struktur portal, pasangan dinding menyebabkan kenaikan pada kekuatan dan kekakuan struktur dan maksimum drift pada struktur dengan infill wall lebih kecil daripada drift pada model bare frame. Penelitian serupa dilakukan oleh Himawan Indarto (2016) mengenai pengaruh pasangan dinding bata pada respon dinamik struktur gedung akibat beban gempa. Adanya pasangan dinding bata pada sistem struktur akan mempengaruhi perilaku dari respon dinamik struktur pada saat terjadi gempa. Dari hasil analisis struktur dengan Metode Riwayat Waktu (Time History Analysis) menggunakan gempa El-Centro, didapatkan perbedaan nilai base shear yang cukup signifikan antara struktur dengan dinding bata yang dipasang monolit dengan struktur tanpa dinding bata.

Studi tentang respon infilled frame structures juga dilakukan oleh Dorji dan tambiratnam (2009). Hubungan antara frame dengan dinding pengisi dimodelkan dengan gap. Kekakuan gap dicari dengan trial and error dan dibandingkan dengan penelitian lain. Analisa beban gempa pada penelitian ini dilakukan dengan time history untuk mencari kekuatan gedung dengan dinding pengisi, fenomena soft-storey, defleksi, periode alami, dan tegangan-tegangan yang terjadi. Hasil penelitian ini mengindikasikan bahwa modulus elastis dinding pengisi sangat berpengaruh terhadap nilai periode getar, displacement, dan interstory-drift. Semua respon ini menurun seiring dengan ditambahnya modulus elastisitas. Semakin besar bukaan dinding pengisi maka nilai displacement akan meningkat. Disisi lain, ketebalan dinding pengisi terhadap keseluruhan respon tidak begitu berpengaruh terutama periode getar alaminya.

Jain dan Murty (2000) telah meneliti pengaruh yang menguntungkan dari pemakaian dinding pasangan batu terhadap kinerja seismik struktur, didapati hasil panel dinding pasangan batu meningkatkan kekuatan, kekakuan, daktilitas dan disipasi energi dari gedung. Hasil penelitian Tanjung (2016) yang meneliti tentang pengaruh dinding bata merah terhadap ketahanan lateral struktur beton bertulang menunjukkan penggunaan bata merah sebagai dinding pengisi menghasilkan peningkatan ketahanan lateral struktur hingga lebih dari 20, ketahanan lateral struktur beton bertulang akan semakin meningkat jika dinding pengisi diplester pada kedua sisinya dan adanya dinding pengisi berupa bata merah akan menunda keruntuhan struktur pada struktur beton bertulang.

Pada penelitian yang telah dilakukan oleh Febbrian (2014) yang melakukan evaluasi kinerja bangunan gedung hotel di daerah karanganyar dengan memakai analisa beban gempa ekuivalen statik dan dinamik respons spektrum menunjukan hasil simpangan antar lantai yang dihasilkan oleh kedua tipe analisis beban gempa tidak jauh berbeda pada setiap lantainya pada arah $\mathrm{X}$ bangunan, sedangkan pada arah $\mathrm{Y}$ menunjukan perbedaan yang lebih besar. Hasil simpangan tersebut secara keseluruhan masih memenuhi syarat kinerja batas layan dari struktur bangunan tersebut.

Dalam penelitian Anggen (2014) menunjukkan bahwa hasil evaluasi kinerja struktur dengan gempa time history rencana dan aktual memiliki hasil yang berbeda, dimana pada gempa rencana seluruh tingkat nilai interstory drift yang dihasilkan aman pada kedua kondisi layan dan ultimate. Sedangkan pada analisa kinerja struktur dengan gempa aktual didapati sebagian besar tingkat struktur memilki nilai interstory drift yang melebihi batas layan maupun ultimate.

\section{Gempa Bumi}

Gempa bumi adalah bergetarnya permukaan tanah karena pelepasan energi secara tiba-tiba akibat dari pecah/slipnya massa batuan dilapisan kerak bumi. Akumulasi energi yang dilepaskan dihasilkan dari pergerakan lempeng tektonik akibat gaya gravitasi, pergerakan lempeng tersebut mengakibatkan adanya regangan/tegangan pada batuan, ketika tegangan maksimum batuan terlampaui maka terjadi pelepasan energi (Prawirodikromo W., 2012). Energi yang dilepaskan pada pusat patahan akan merambat ke segala arah sebagai gelombang seismik hingga mencapai ke permukaan tanah. Getaran permukaan tanah yang diakibatkan oleh aktivitas/pergerakan lempeng tektonik disebut gempa tektonik.

Richart et el., 1970 menjelaskan bahwa dari kedua kelompok gelombang tersebut, gelombang permukaan membawa energi yang lebih besar dari pada gelombang bodi. Namun..dikarenakan gelombang bodi memilki kecepatan rambat lebih besar, dimana gelombang yang paling cepat merambat adalah 
$P$-wave disusul oleh $S$-wave dan kemudian $R$ wave. Maka dapat disimpulkan gelombang bodi akan tercatat lebih dahulu dibanding gelombang permukaan.

\section{Degree of Freedom}

Derajat kebebasan (degree of freedom) adalah derajat indenpendensi yang diperlukan untuk menyatakan posisi suatu sistim pada setiap saat. Apabila suatu titik yang ditinjau mengalami perpindahan tempat secara horizontal, vertikal dan ke samping misalnya, maka sistem tersebut mempunyai 3 derajat kebebasan. (Widodo, 2000).

Menurut Mario Paz (1996), pada umumnya struktur berkesinambungan (continuous structure) mempunyai jumlah derajat kebebasan (number degree of freedom) tak berhingga. Namun dengan proses idealisasi atau seleksi, sebuah model matematis yang tepat dapat mereduksi jumlah derajad kebebasan menjadi suatu jumlah diskrit dan untuk beberapa keadaan dapat menjadi berderajat kebebasan tunggal (Single Degree of Freedom).

\section{Drift Ratio}

Drift merupakan nilai ratio antara simpangan yang terjadi pada lantai yang ditinjau terhadap tinggi lantai tersebut. Nilai total drift atau sering juga disebut sebagai perpindahan elastis antar lantai pada lantai $\mathrm{x}\left(\delta_{\mathrm{ex}}\right)$ bisa dihasilkan melalui olahan dari output nilai simpangan gedung. Perpindahan elastis diperoleh dengan cara mencari selisih simpangan yang terjadi pada lantai yang ditinjau dan lantai di bawahnya. Faktor pembesaran defleksi $\left(\mathrm{C}_{\mathrm{d}}\right)$ dan faktor keutamaan bangunan $\left(\mathrm{I}_{\mathrm{e}}\right)$ harus diikutkan dalam menentukan nilai story drift. SNI 1726:2012 mensyaratkan bahwa besarnya nilai story drift $\left(\delta_{X}\right)$ harus ditentukan melalui persamaan (1)

$$
\delta_{X}=\frac{C_{d} \delta_{x}}{I_{e}} \leq \Delta_{a}
$$

Kinerja batas ultimit dari nilai story drift akan diperoleh dalam penelitian ini. Gedung akan dikatakan aman apabila nilai story drift hasil analisis tidak melampaui batas yang diijinkan $\left(\Delta_{a}\right)$ menurut SNI 1726:2012.

\section{Metode Penelitian}

Gedung K.H. Ibrahim (twin building) dimodelkan dengan program numerik secara 3 dimensi dengan 2 model open frame (struktur portal tanpa dinding) dan model infill frame (struktur portal dengan dinging pengisi). Gedung yang ditinjau merupakan gedung dengan fungsi sebagai fasilitas pendidikan sehingga masuk dalam kategori resiku IV dan nilai faktor keutamaan bangunan (I) sebesar 1,5. Sistem struktur gedung adalah dual sistem antara SRPMK (Struktur Rangka Pemikul Momen Khusus) dan dinding Geser (shearwall) pada bagian lift, sering juga disebut sebagai corewall. Dalam tabel SNI 1726:2012 tipe struktur yang seperti ini mensyaratkan nilai koefisien modifikasi (R) sebesar 7. Gedung terdiri dari 7 lantai dengan elevasi tertinggi yaitu 31,6 m. Gedung berdiri pada tanah dengan kelas situs sedang (SD) dengan nilai $\mathrm{N}_{\text {rata-rata }}$ sebesar 48,6. Batasan nilai drift ratio yang disyaratkan mengacu pada SNI 1726:2012 Tabel 16 untuk kategori resiko IV dengan kondisi struktur seperti yang seudah dideskripsikan adalah sebesar $1 \%$.

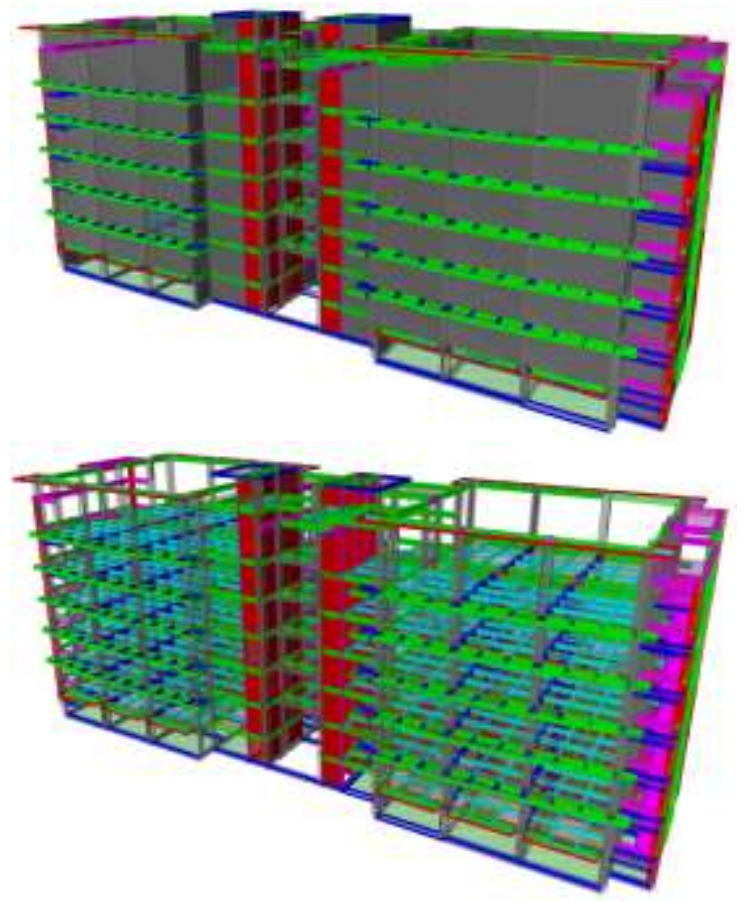

GAMBAR 1. Model struktur gedung KH Ibrahim (a) Infill frame (b) open frame 
TABEL 1. Distribusi gaya gempa statik ekuivalen berdasar SNI 1726:2002 dan SNI 1726:2012

\begin{tabular}{|c|c|c|c|}
\hline \multirow{2}{*}{ Struktur } & \multicolumn{3}{|c|}{ Kategori resiko } \\
\hline & I atau II & III & IV \\
\hline $\begin{array}{l}\text { Struktur, selain dari struktur dinding geser batu bata, } 4 \\
\text { tingkat atau kurang dengan dinding interior, partisi, langit- } \\
\text { langit dan sistem dinding eksterior yang telah didesain } \\
\text { untuk mengakomodasi simpangan antar lantai tingkat. }\end{array}$ & $0,025 \mathrm{~h}_{\mathrm{sx}}$ & $0,020 \mathrm{~h}_{\mathrm{sx}}$ & $0,015 \mathrm{~h}_{\mathrm{sx}}$ \\
\hline Struktur dinding geser kantilever batu bata & $0,010 \mathrm{~h}_{\mathrm{sx}}$ & $0,010 \mathrm{~h}_{\mathrm{sx}}$ & $0,010 \mathrm{~h}_{\mathrm{sx}}$ \\
\hline Struktur dinding geser batu bata lainnya & $0,007 \mathrm{~h}_{\mathrm{sx}}$ & $0,007 \mathrm{~h}_{\mathrm{sx}}$ & $0,007 \mathrm{~h}_{\mathrm{sx}}$ \\
\hline Semua struktur lainnya & $0,020 \mathrm{~h}_{\mathrm{sx}}$ & $0,015 \mathrm{~h}_{\mathrm{sx}}$ & $0,010 \mathrm{~h}_{\mathrm{sx}}$ \\
\hline
\end{tabular}

Beberapa referensi yang digunakan sebagai acuan dalam analisis diantaranya mengacu pada PPURG 1987 dan SNI 1727:2013 untuk pembebanannya. Untuk analisa beban gempa baik berupa statik ekuivalen, spectrum response dan time history mengacu pada peraturan SNI 1726:2012 serta FEMA 45 NEHRP Recommended Provisions: Design Examples. Federal Emergency Management Agency.

Analisis struktur dilakukan dengan bantuan program numerik secara analisis linear. Periode getar alami struktur dari hasil perhitungan nilai pendekatannya $\left(\mathrm{T}_{\mathrm{a}}\right)$ nilai batas maksimum $\left(\mathrm{C}_{\mathrm{u}} \mathrm{T}_{\mathrm{a}}\right)$ secara berturut-turut diperoleh sebesar 0,650 detikdan 0,934 detik. Hasil pemodelan struktur dengan program numerik untuk model gedung infill frame, nilai periode struktur gedung diperoleh hasil lebih kecil daripada nilai periode pendekatannya yaitu sebesar 0,398 detik pada kondisi inersia balok dan kolom utuh dan 0,447 detik untuk kondisi penampang efektif (balok dan kolom tereduksi). Sebaliknya pada model Open frame, nilai periode gedung melampaui batas atas dari periode pendekatannya yaitu sebesar 1,163 detik untuk kondisi penampang utuh dan 1,181 detik untuk kondisi penampang tereduksi.

\section{Spektrum Response}

Respons spectrum (RS) adalah suatu spektrum yang disajikan dalam bentuk grafik plot antara periode getar struktur $\mathrm{T}$, lawan respons-respons maksimumnya untuk suatu rasio redaman dan beban gempa tertentu. Respons maksimum dapat berupa simpangan maksimum (Spectral Displacement, SD), kecepatan maksimum (Spectral Velocity, SV) atau percepatan maksimum (Spectral Acceleration, SA) suatu massa struktur dengan derajat kebebasan tunggal (Single Degree of Freedom, SDOF) (Prawirodikromo, 2012).

Berdasar peta gempa SNI 1726:2012 untuk lokasi bangunan tersebut nilai $\mathrm{S}_{\mathrm{s}}$ diperoleh sebesar 1,039 g sedangkan $S_{1}$ sebesar 0,396 g. dengan perhitungan mengacu pada peraturan yang berlaku diperoleh nilai $S_{D S}$ dan $S_{D 1}$ berturut-turut sebesar 0,693 g dan 0,264 g. Grafik spectrum response ditunjukkan pada Gambar 2.

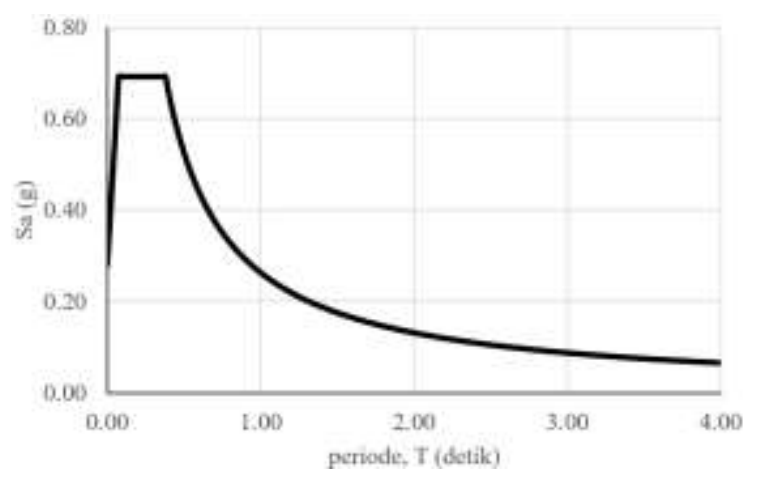

GAMBAR 2. Respon spectrum rencana berdasarkan SNI 1726:2012

\section{Gaya Geser Seismik}

Gaya Geser dasar seismik ragam pertama (statik ekuivalen) gedung diperoleh melalui hasil kali koefisien geser seismik $\left(\mathrm{C}_{\mathrm{s}}\right)$ dan berat total struktur $\left(\mathrm{W}_{\mathrm{t}}\right)$, Persamaan (2). Gaya geser tersebut didistribusikan ke masing-masing lantai sesuai dengan proporsinya mengikuti formula yang telah disyaratkan dalam SNI 1726:2012, Persamaan (3) dan Persamaan (4).

$$
\begin{aligned}
& V=C_{s} W_{t} \\
& C_{v x}=\frac{W_{x} h_{x}{ }^{k}}{\sum_{i=1}^{n} W_{i} h_{i}{ }^{k}} \\
& F_{x}=C_{v x} V
\end{aligned}
$$

Dengan $\mathrm{V}$ adalah gaya geser dasar bangunan; Fx adalah gaya lateral akibat gempa; $\mathrm{C}_{\mathrm{vx}}$ adalah 
faktor distribusi vertikal; dan $\mathrm{k}$ merupakan konstanta yang besarnya ditentukan berdasarkan nilai periode struktur..

TABEL 2. Distribusi gaya gempa pada tiap lantai

\begin{tabular}{cccc}
\hline Lt. & $\begin{array}{c}\text { Berat } \\
\text { Wx }\end{array}$ & $\begin{array}{c}\text { Infill } \\
\text { frame } \\
\text { Vx }\end{array}$ & $\begin{array}{c}\text { Open } \\
\text { Frame } \\
\text { Vy }\end{array}$ \\
\hline RM & 1496,19 & 300,45 & 225,54 \\
\hline ATAP & 16784,33 & 3442,10 & 2562,12 \\
\hline LT 5 & 25071,88 & 7053,55 & 5156,90 \\
\hline LT 4 & 23004,03 & 9757,08 & 7047,93 \\
\hline LT 3 & 23004,03 & 11860,10 & 8470,98 \\
\hline LT 2 & 23538,94 & 13409,72 & 9475,14 \\
\hline LT 1 & 23798,24 & 14383,97 & 10068,11 \\
\hline LT,G & 19628,98 & 14719,99 & 10250,41 \\
\hline SB & 12908,63 & 14719,99 & 10250,41 \\
\hline
\end{tabular}

Terlihat pada Tabel 2 bahwa nilai gaya geser pada struktur infill frame pada semua lantai lebih besar daripada nilai gaya geser pada open frame. Dinding pengisi yang tidak diperhitungkan kekakuannya pada model open frame menambah kekakuan dari model struktur infill frame. Meningkatnya kekakuan diikuti dengan meningkatnya gaya gempa pada masing-masing lantai tersebut. Gaya perlantai berbanding lurus dengan nilai story shear yang merupakan komulatif beban gempa dari tiap lantainya. Untuk gambaran lebih jelasnya dapat dilihat pada Gambar 3 dan Gambar 4

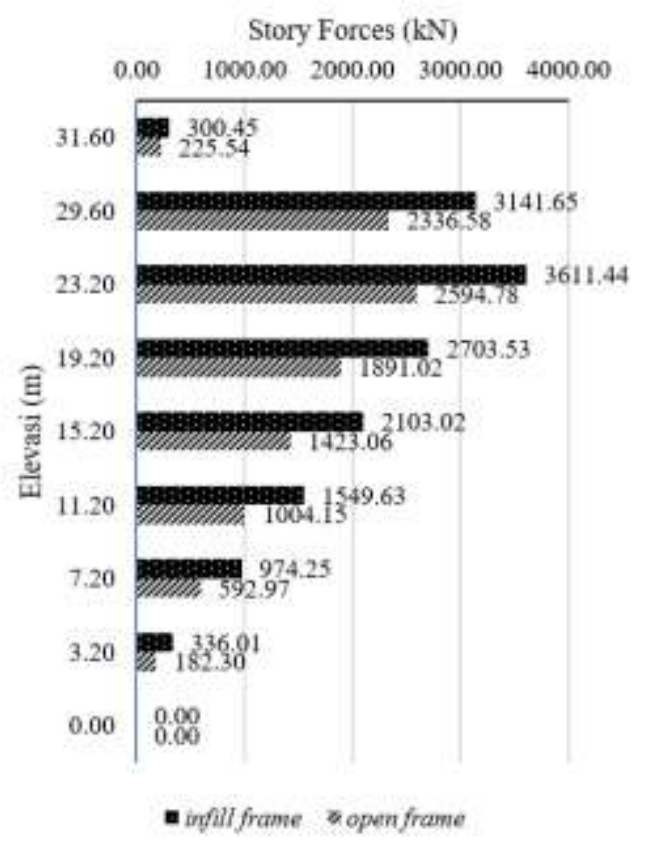

GAMBAR 3. Gaya gempa statik ekuivalen per lantai

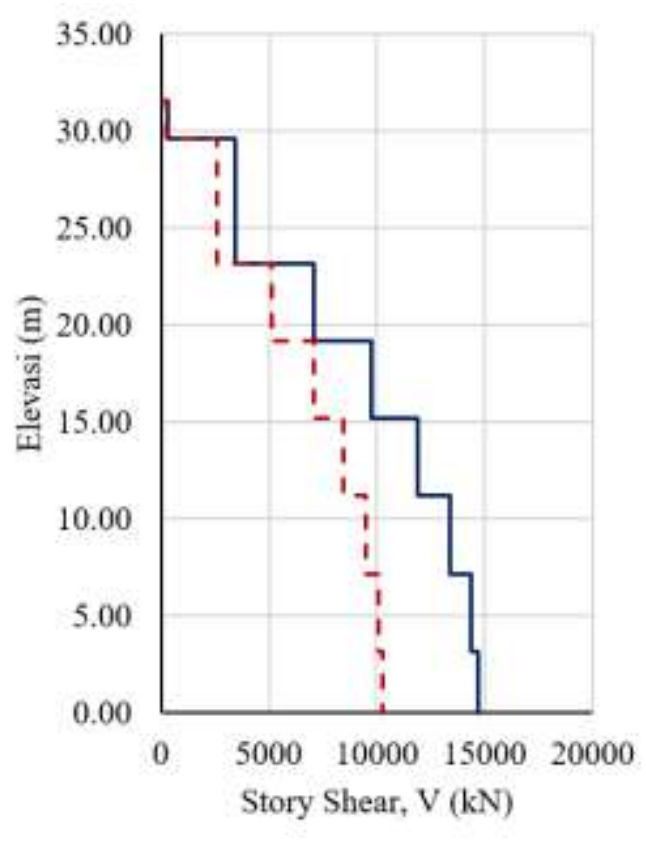

- Infill Frame -- Open Frame

GAMBAR 4. Gaya geser gempa statik ekuivalen

\section{Time History}

Data time history atau riwayat waktu didapat dari data catatan akselerogram gempa saat gempa terjadi disuatu wilayah. Sehingga analisis time history dapat merepresentasikan bagaimana respon suatu model struktur terhadap percepatan gempa rencana.

Sesuai yang tercantum pada SNI 1726:2012 apabila tidak ditemukan data rekaman gempa pada daerah yang ditinjau maka disyaratkan untuk digunakan 3 buah rekaman gempa dari daerah lain yang sesuai parameternya dan kemudian diambil nilai respon maksimumnya atau tujuh rekaman gempa untuk kemudian diambil nilai rerata responnya. Pada penelitian ini dipilih 3 rekaman gempa yang diambil dari situs peer.berkeley.edu yang mirip dengan kondisi kegempaan di lokasi penelitian yaitu di Provinsi Daerah Istimewa Yogyakarta (DIY). Respon spectrum dari tiga gempa yang dipilih harus disesuaikan dengan spectrum response target di lokasi penelitian sebelum dianalisis respon-respon gempanya terhadap bangunan. Rekaman kejadian gempa dimodifikasi agar respons spektranya menyerupai respons spektrum desain (Gambar 8). Tiga rekaman kejadian gempa yang dipilih diantaranya adalah: Northern California (NC), Gambar 5; Superstition Hills (SH), Gambar 6; dan Imperial Valley (IV) Gambar 7. 


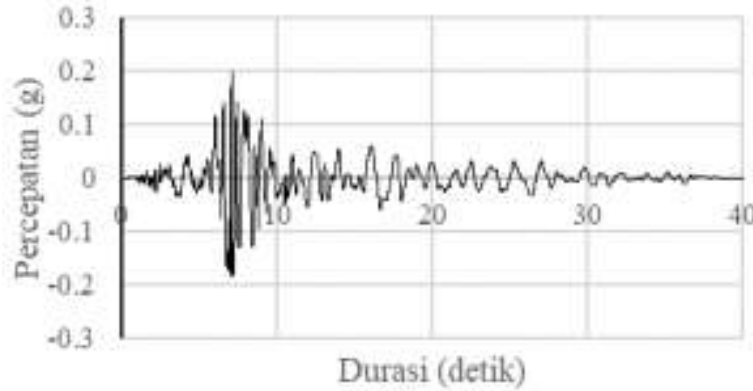

(a)

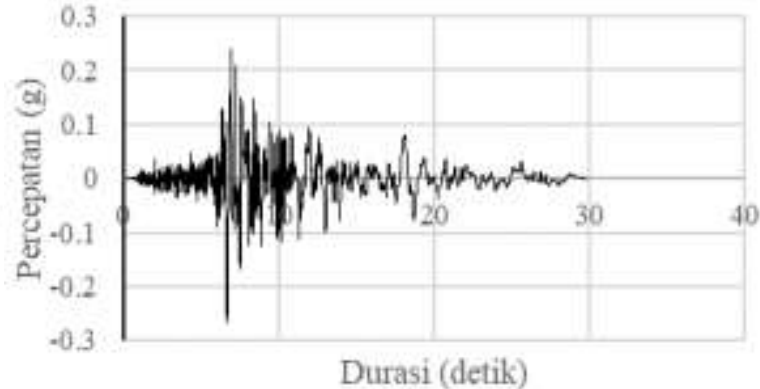

(b)

GAMBAR 5. Rekaman riwayat waktu Gempa Northern California termodifikasi (a) Northern California arah sumbu x (b) Northern California arah sumbu y

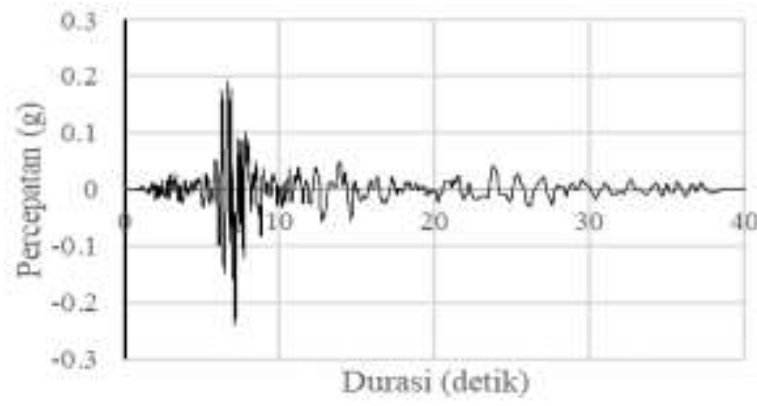

(a)

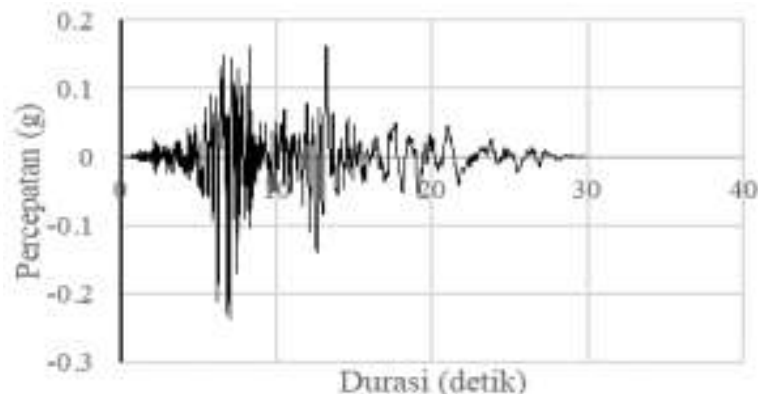

(b)

GAMBAR 6. Rekaman riwayat waktu Gempa Superstition Hills termodifikasi (a) Superstition Hills arah sumbu x (b) Superstition Hills arah sumbu y

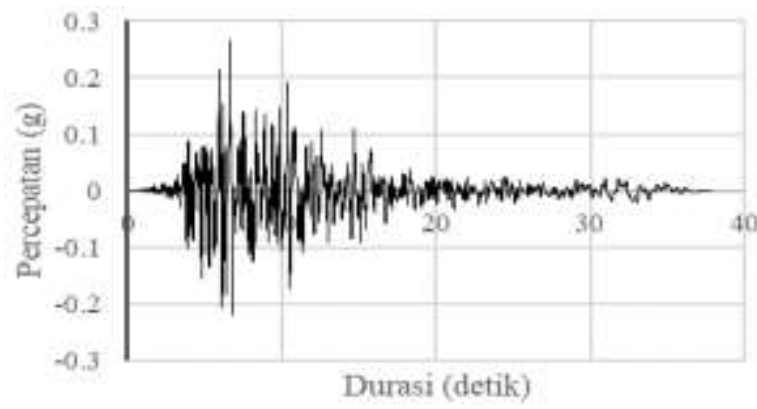

(a)

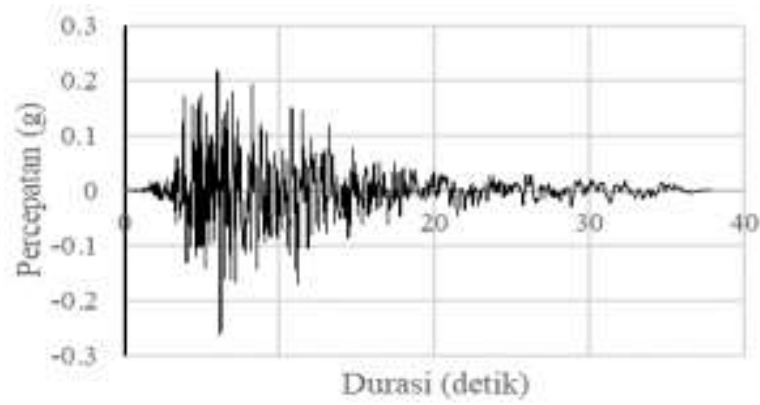

(b)

GAMBAR 7. Rekaman riwayat waktu Gempa Imperial Valley termodifikasi (a) Imperial Valley arah sumbu x (b) Imperial Valley arah sumbu y
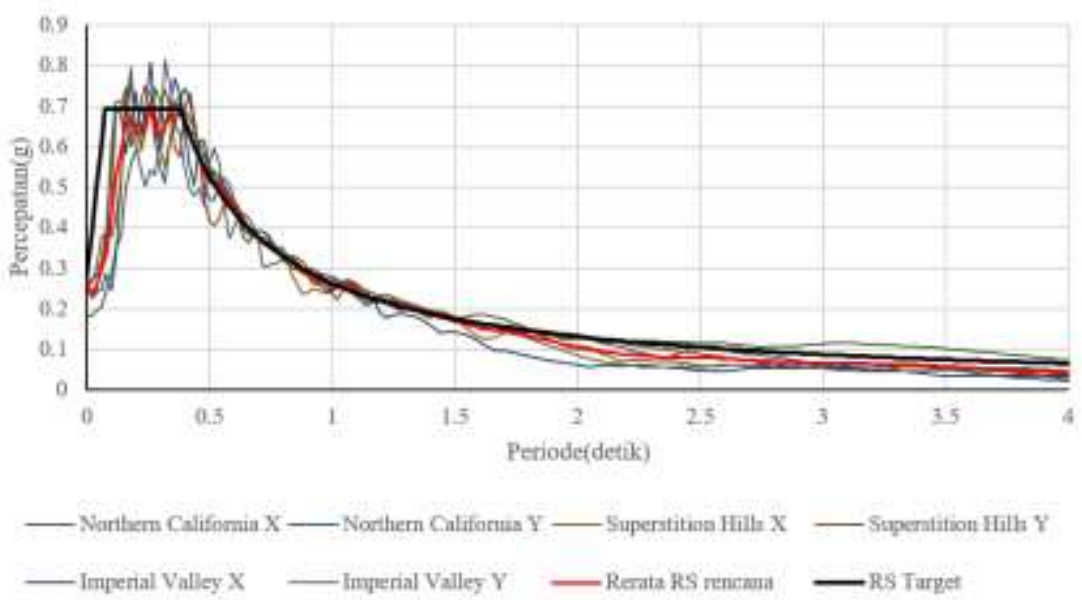

GAMBAR 8. Respons spectrum rekaman gempa rencana dengan respons spectrum target 


\section{Periode Getar Struktur}

Hasil analisis dengan bantuan program numerik diambil sebanyak 18 mode shape, karena pada mode shape ke-18 syarat rasio partisipasi massa sebesar 90\% terpenuhi pada masing-masing sumbu utama struktur (SNI 1726:2012 Pasal 7.9.1). Diperoleh nilai periode getar struktur pada model open frame lebih besar dari pada periode getar yang dihasilkan model infill frame. Sebaliknya nilai frekuensi yang dihasilkan pada model open frame justru lebih kecil daripada frekuensi yang dihasilkan pada model infill frame. Hasil tersebut menunjukkan bahwa penambahan dinding pengisi pada model gedung mampu menambah kekakuan struktur
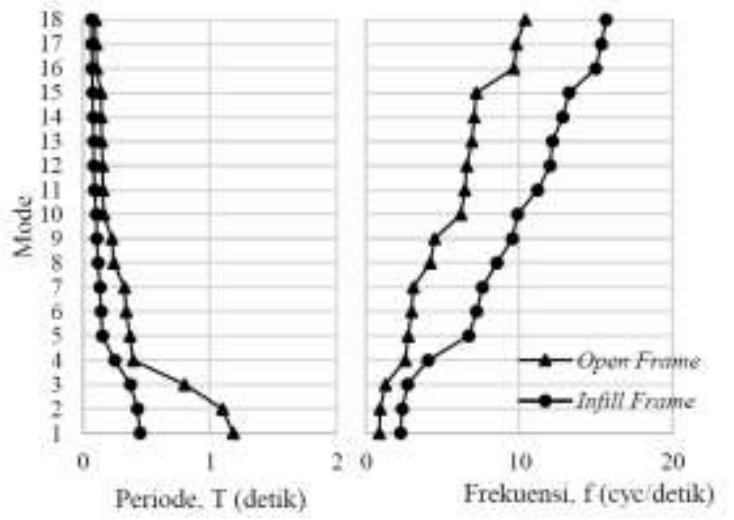

GAMBAR 9. Periode dan frekuensi gedung K.H. Ibrahim

\section{HASIL DAN PEMBAHASAN}

Data perpindahan yang diambil merupakan empat titik ujung dari salah satu gedung pada twin bulding yang ditinjau dengan kode $\mathrm{J} 1, \mathrm{~J} 7$, J24, dan J33 (Gambar 10). Nilai simpangan dan drift ratio diambil dari respon struktur akibat beban Respon Spektrum sumbu-x dan sumbu-y (RSX dan RSY), Northern California sumbu-X dan sumbu-y (NCX dan NCY), Superstition Hills sumbu-x dan sumbu-y (SHX dan SHY), dan Imperial Valley sumbu-x dan sumbu-y (IVX dan IVY).

Terlihat pada Gambar 11 dan Gambar 12 bahwa semua lantai masih dalam kondisi aman. Hal ini ditunjukkan dengan indikator nilai interstory drift pada tiap lantai yang masih berada dalam batas ijinnya baik nilai pada sumbu-x maupun pada sumbu-y. Kekakuan tambahan yang disumbangkan oleh adanya dinding pengisi pada model infill frame mampu mengurangi besarnya displacement pada joint-joint terluar tiap lantainya. Hasil yang serupa dengan penelitian Tidke dan Jangave (2016) yang menyebutkan bahwa pasangan dinding mampu membuat drift pada model infill frame lebih kecil daripada open frame.

Lebih dari itu, jika dibandingkan antara open dan infill frame model baik arah sumbu-x maupun sumbu-y, keberadaan dinding pengisi yang posisinya cukup teratur pada model infill frame juga mampu menyeragamkan titik-titik simpangan pada masing-masing lantainya. Simpangan terbesar secara garis besar disebabkan oleh Gempa Northern California. Pengaruh penambahan dinding pengisi mampu menurunkan nilai displacement yang terjadi hingga hampir 6 kali lipat dari analisis secara open frame.

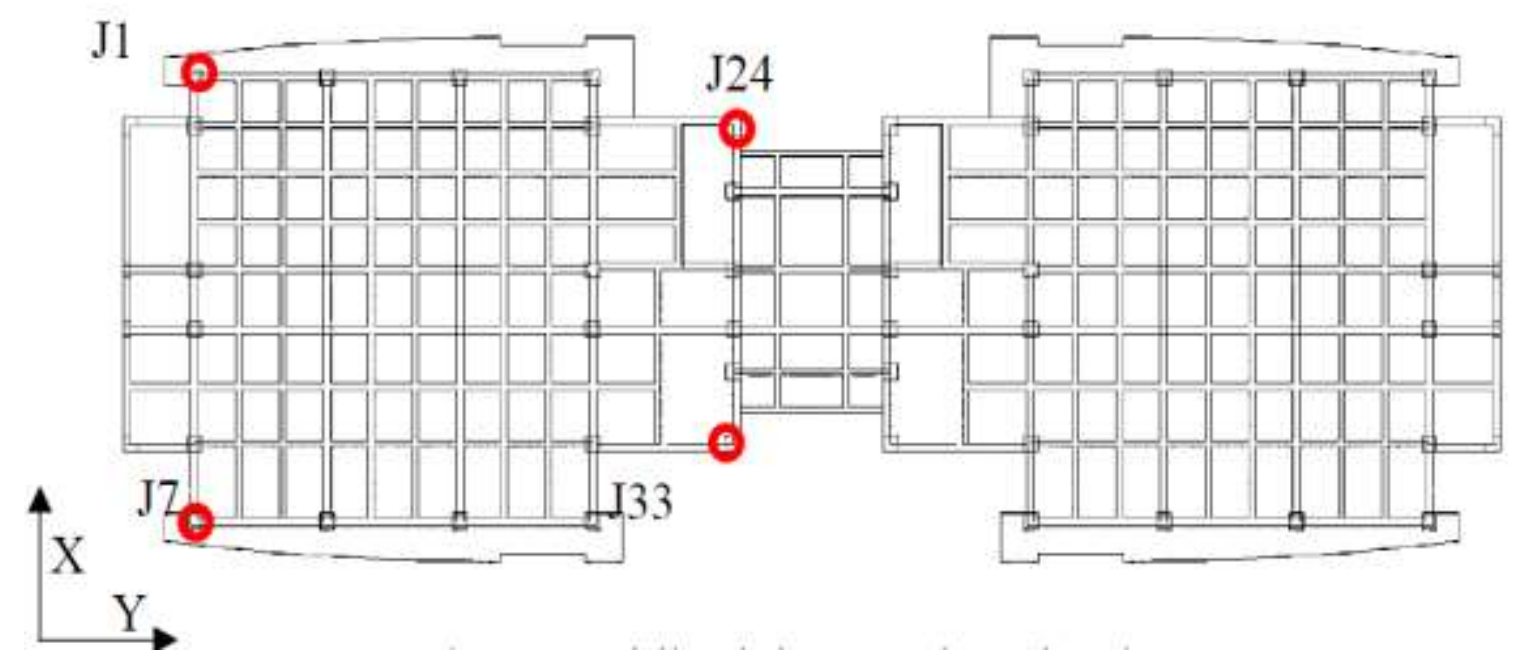

GAMBAR 10. Denah titik tinjauan nilai displacement 


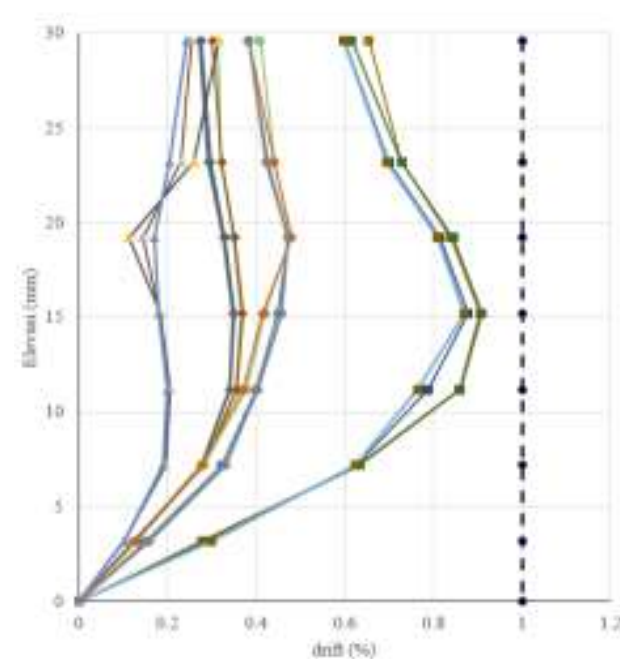

(a)

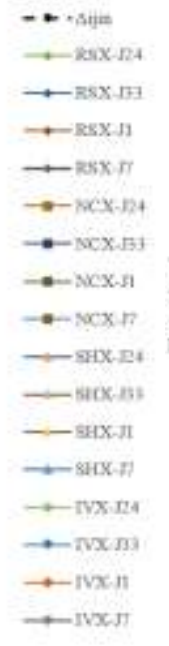

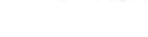

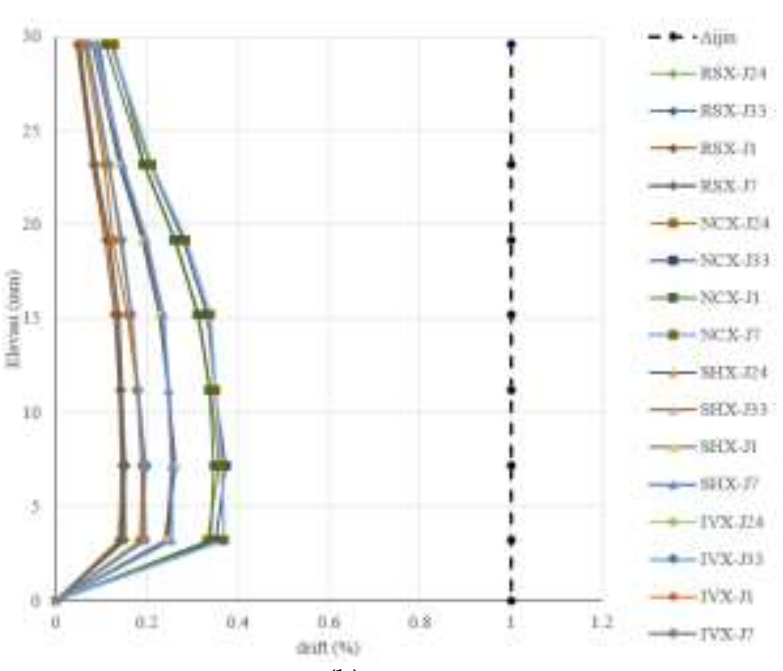

(b)

GAMBAR 11. Story drift untuk arah sumbu-x semua variasi beban gempa pada tiap lantai gedung. (a) Open frame (b) infill frame

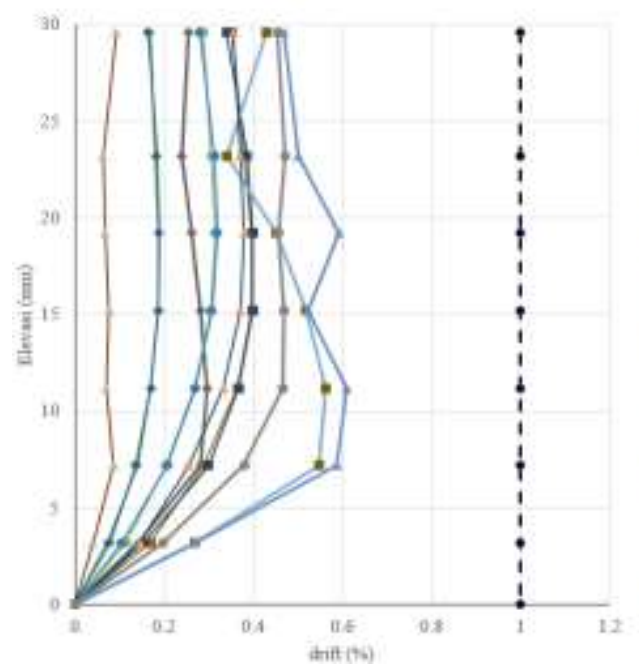

(a)

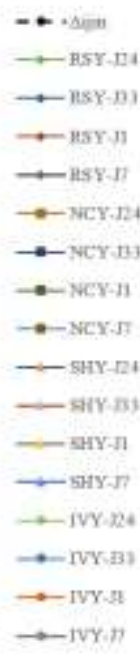

vin

GAMBAR 12. Story drift untuk arah sumbu-y semua variasi beban gempa pada tiap lantai gedung. (a) Open frame

(b) Infill frame

Tampak pada Gambar 13 yang menunjukkan rasio rerata drift ratio model open frame terhadap infill frame dari keempat titik tinjauan untuk setiap jenis pembebanan gempa pada masing-masing lantai. Pola penurunan nilai displacement untuk tiap jenis pembebanan gempa memiliki pola kecenderungan yang sama, dimana nilai rasio terbesar terletak pada lantai teratas sedangkan rasio terkecil terletak pada lantai terbawah. Pola kecenderungan ini erat kaitannya dengan besarnya gaya geser yang diterima tiap lantainya. Gambar 14 menggambarkan rasio antara rerata gaya geser model open frame terhadap infill frame untuk setiap jenis pembebanan gempa pada masing-masing lantai menunjukkan pola kecenderungan yang hampir mirip dengan Gambar 13 Hal ini menunjukkan adanya kesesuaian dengan teori bahwa Gaya (F) berbanding lurus dengan nilai displacement (U) yang terjadi. Dari kedua diagram tersebut terlihat bahwa pengaruh paling besar baik terhadap nilai displacement maupun gaya gesernya adalah dampak dari gempa Superstition Hills.

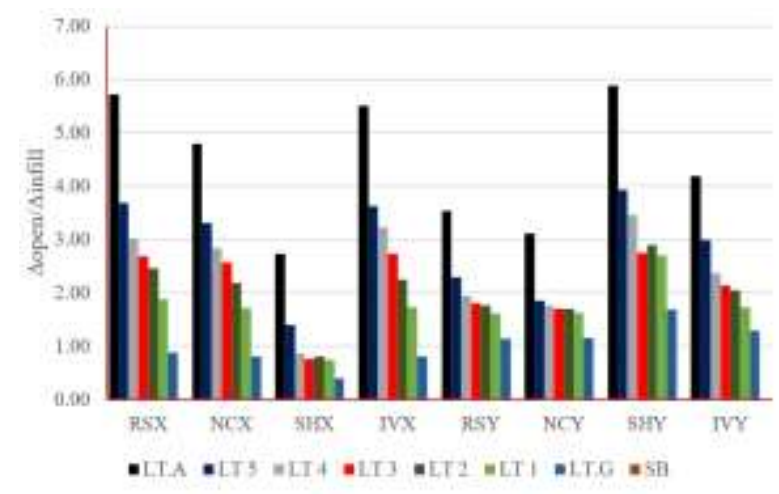

GAMBAR 13. Pengaruh penambahan dinding pengisi pada nilai drift ratio, $\Delta$ 


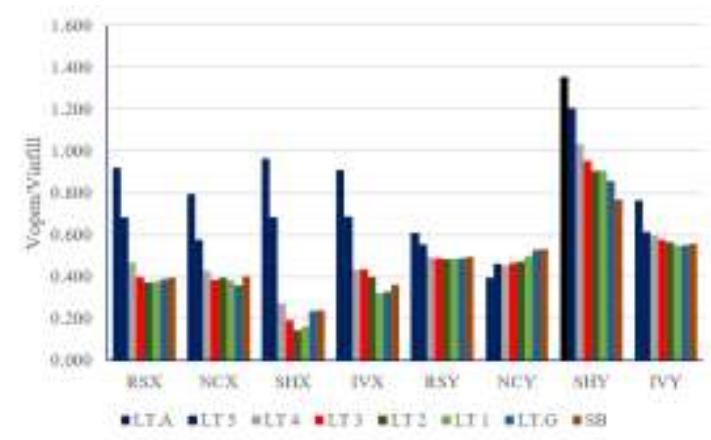

GAMBAR 14. Pengaruh penambahan dinding pengisi pada nilai gaya geser lantai, $\mathrm{V}$

\section{KESIMPULAN}

Berdasarkan hasil analisis dapat diperoleh kesimpulan bahwa gedung KH Ibrahim yang terletak di Daerah Istimewa Yogyakarta masih dalam kondisi aman dengan nilai interstory drift pada kedua model yang ditinjau (open dan infill frame) masih belum melewati batas ijinnya yaitu $1 \%$. Adanya penambahan dinding pengisi berpengaruh cukup besar terhadap nilai gaya geser dan simpangan yang terjadi. Dinding pengisi yang ditambahkan pada model struktur meningkatkan kekakuan gedung sehingga mampu memperkecil nilai simpangan yang terjadi. Tercatat dalam hasil penelitian bahwa nilai simpangan terbesar yang dihasilkan oleh model open frame hampir sama dengan 6 kali simpangan yang terjadi pada model infill frame. Sementara itu, bertambahnya kekakuan gedung berbanding lurus dengan besaran gaya geser yang terjadi dan berdasarkan hasil penelitian diperoleh hasil bahwa rasio terbesar antara gaya geser dasar pada model open frame terhadap gaya geser pada infill frame adalah sebesar 0,24. Dengan kata lain nilai base shear pada model infill frame adalah sebesar 4,2 kali lipat base shear pada model open frame.

\section{DAFTAR PUSTAKA}

Anggen, W., Budi, A. S., \& Gunawan, P. (2014). Evaluasi Kinerja Struktur Gedung Bertingkat Dengan Analisis Dinamik Time History Menggunakan Etabs (Studi Kasus: Hotel Di Daerah Karanganyar). Matriks

Teknik Sipil, 2(3).

BSN. (2012). SNI 1726:2012 Tata Cara Perencanaan Ketahanan Gempa Untuk Struktur Bangunan Gedung dan Non Gedung. Badan Standarisasi Nasional, Bandung.
BSN. (2013). SNI 1727:2013 Beban Minimum Untuk Perancangan Bangunan Gedung dan Struktur Lain. Badan Standarisasi Nasional, Bandung.

BSN. (2013). SNI 2847:2013 Persyaratan Beton Struktural Untuk Bangunan Gedung. Badan Standarisasi Nasional, Bandung.

Dorji, J., \& Thambiratnam, D. P. (2009). Modelling and analysis of infilled frame structures under seismic loads. The Open Construction \& Building Technology Journal, 3, 119-126.

FEMA-451, 2006. NEHRP Recommended Provisions: Design Examples. Federal Emergency Management Agency. Washington, D.C.

Febbrian, D. B. (2014). Evaluasi Kinerja Gaya Gempa pada Gedung Bertingkat Dengan Analisis Respon Spektrum Berdasarkan Base Share, Displacement, dan Drift Menggunakan Software Etabs (Studi Kasus: Hotel Di Daerah Karanganyar).

Indarto, H., \& Pardoyo, B. (2016). Pengaruh Pasangan Dinding Bata pada Respon Dinamik Struktur Gedung Akibat Beban Gempa. Jurnal Teknik Sipil dan Perencanaan, 18(1), 9-14.

Murty, C. V. R., \& Jain, S. K. (2000, January). Beneficial influence of masonry infill walls on seismic performance of RC frame buildings. In 12th world conference on earthquake engineering.

Paz, Mario. (1993). Dinamika Struktur: Teori dan Perhitungan. Jakarta: Penerbit Erlangga.

Prawirodikromo, Widodo. (2000). Respon Dinamik Struktur Elastik. Yogyakarta: UII Press.

Prawirodikromo, Widodo. (2012). Seismologi Teknik dan Rekayasa Kegempaan. Yogyakarta: Pustaka Pelajar.

Richart, F.E, Hall J.R dan Woods R.D. 1970. Vibrations of Soils and Foundations. New Jersey: Pretince Hall.

SKBI - 1.3.53.1987, 1987, Pedoman Perencanaan Pembebanan Untuk Rumah dan Gedung (PPURG). Yayasan Penerbit Pekerjaan Umum, Jakarta. 
Tanjung, J., \& Maidiawati, M. (2016). Studi Eksperimental tentang Pengaruh Dinding Bata Merah Terhadap Ketahanan Lateral Struktur Beton Bertulang. Journal of Civil Engineering, 23(2), 99-106.

Tidke, K., \& Jangave, S. (2016, July). Seismic Analysis of Building with and Without Infill Wall. International Journal of Innovative Research in Science,
Engineering and Technology Vol. 5 (7) (12646-12652).

PENULIS:

Muhammad Ibnu Syamsi

Program Studi Teknik Sipil, Fakultas Teknik, Universitas Muhammadiyah Yogyakarta, Bantul.

Email: syamsibnu@umy.ac.id 